\author{
Гаман Петро Ілліч, \\ доктор наук з державного управління, дочент, \\ начальник відділу публічного управління цивільним захистом \\ науково-дослідного центру заходів цивільного захисту, \\ Український науково-дослідний інститут цивільного захисту, \\ м. Київ, Україна
}

ORCID iD 0000-0002-3239-8936

e-mail:haman_p.i@ukr.net

\author{
Гаман Наталія Олександрівна, \\ кандидат наук з державного управління, \\ старший викладач кафедри маркетингу, \\ менеджменту та управління бізнесом, \\ Уманський державний педагогічний університет імені Павла Тичини, \\ м. Умань, Україна
}

ORCID iD 0000-0003-4999-6163

e-mail:haman_n.o@ukr.net

\title{
ЕКОНОМІЧНА БЕЗПЕКА НАВЧАЛЬНОГО ЗАКЛАДУ ЯК СКЛАДОВА ПРОЦЕСУ ДЕРЖАВНОГО УПРАВЛІННЯ ОСВІТОЮ
}

\begin{abstract}
Анотація. Цивілізачійні прочеси початку XXI століття означені глобалізацією комунікації, формуванням ідеології інформачійного суспільства, які вирішальним чином впливають на міжнародне середовище, радикально змінюють міжнародну політику, національні, зовнішньо- і внутрішньополітичні доктрини, зумовлюють необхідність з'ясування пріоритетів та розробки оптимальних програм у політичній, економічній, соціальній та культурній сферах. Система освіти будь-якої держави є невід `ємною частиною загальної сукупності її соціально-економічних відносин. Реалізація адекватного аналізу функціонування та розвитку освітніх прочесів і систем, організація есективного управління ними, забезпечення відповідного рівня якості результатів діяльності фактично неможливі без урахування їх взаємодіі з навколишнім середовищем, а також мінімізації ризиків виникнення конфліктів інтересів. Загальна безпека країни може бути забезпечена лише за рахунок одночасного вирішення цього питання в ряді різноманітних галузей, а саме: військовій, технічній, технологічній, економічній, фрінансовій, політичній, екологічній, інформачійній тощо. Інформачійна домінанта посилює ефект глобальної політики, визначає значущість країн у світовій ієрархії, виступає чинником міжнародних впливів, інструментом дипломатії та глобальної стратегії світового порядку. Для вищої освіти України такі процеси розглядаються через призму завдань входження до Європейського простору вищої освіти (ЄПВО), вихідним концептом якого з 2005 року є реалізація принципів Болонського прочесу. Освітня сфера не може бути винятком із наведеного вище переліку, хоча б у зв 'язку з тим, що першочерговим завдання ії функчіонування є підготовка висококваліфікованих фахівців для всіх без винятку перерахованих галузей. I в такому сенсі аспекти безпеки освіти є визначальними для всіх інших сфер соціально-економічного життя.
\end{abstract}

Ключові слова: заклади вищої освіти; державне управління; інструменти державного управління; безпека; освітні послуги; органи державної влади. 


\section{ВСТУП}

В останні десятиріччя у повній відповідності до суспільних потреб відбувається інтенсивне формування загальної теорії безпеки життєдіяльності світового співтовариства, яка включає всі аспекти від екологічних, економічних, технічних до соціальних, воєнних, політичних. Утвердження і забезпечення права людини на освіту в будь-якій країні $є$ одним із найважливіших обов'язків держави. Це зумовлено тим, що освіта в сучасному глобалізованому й інформатизованому світі все більше стає вирішальним чинником суспільного прогресу і національної безпеки, важливою складовою повного розвитку людської особистості, збільшення поваги до прав і свобод людини. На сьогодні цілком очевидно, що без необхідної освіти людина не зможе забезпечити собі належні умови життя і реалізуватись як особистість, а також усвідомити і захистити свої права. Високий рівень освіченості населення $\epsilon$ важливим чинником, що позитивно впливає на створення сприятливих умов для повної реалізації прав і свобод людини та громадянина.

Постановка проблеми. Становлення української державності безпосередньо пов'язане з актуалізацією проблем державного управління, розвитком науки управління суспільним розвитком, що неможливо без теоретико-методологічного обгрунтування механізмів державного управління, адміністративно-організаційних напрямів державотворення, функцій, структури, повноважень та особливостей органів державної влади усіх рівнів.

Аналіз останніх досліджень і публікацій. Дослідженню проблем організаційно-економічних механізмів управління вищою освітою, диверсифікації джерел іiі фінансування в Україні присвяченонауковіпрацібагатьохучених,зокрема В. Авер'янова, Л. Антошкіної, Г. Атаманчука, П. Єгорова, О. Ковалюка, О. Коротич, Ю. Лисенка, В. Малиновського та ін. Проте окремі проблеми вимагають детальнішого опрацювання. Так, на сьогодні в умовах інноваційного розвитку та інтеграції до європейського освітнього простору потребують глибокого дослідження теоретичні засади з формування нових прогресивних механізмів державного управління вищими навчальними закладами системи Міністерства освіти і науки України.

\section{РЕЗУЛЬТАТИ ДОСЛІДЖЕННЯ}

Роль і призначення системи вищої освіти у країні, погляди на ії головні характеристики, підходи до дослідження та його аспекти не залишаються незмінними, вони трансформуються разом зі змінами, що відбуваються у різно- манітних сферах суспільного та економічного життя в Україні під впливом глобалізаційних процесів та інтернаціоналізації суспільного життя. Завдяки цим трансформаціям актуалізуються нові аспекти дослідження системи вищої освіти у країні, тоді як до інших аспектів інтерес і дослідників, і практиків втрачається. Новим аспектом дослідження системи вищої освіти в Україні слід визнати іiі безпеку. Адже тенденції та явища негативного характеру, що не просто спостерігаються останніми роками у цій системі, а вже набули стійкого характеру, є підстави розглядати як суттєві загрози та небезпеки для системи. Але ж виконувати своє призначення повною мірою система вищої освіти в Україні здатна лише тоді, коли умови іiі функціонування $є$ відносно безпечними.

Освіта - унікальне суспільне явище, що справляє значний вплив на всі аспекти життя і діяльності країни, соціуму, людської цивілізації загалом. В умовах сучасної науково-технічної та інформаційної революції освіта функціонує як складний соціально-економічний організм, який відіграє велику роль у суспільному прогресі людства. Вона $є$ однією з найвагоміших галузей трудової і пізнавальної життєдіяльності. Сучасний етап розвитку системи освіти України характеризується їі реформуванням, пошуком шляхів приведення змісту у відповідність з особистісними запитами учнів, світовими стандартами. Кризові явища в освіті, які спостерігаються нині, пов'язані з становленням України як незалежної держави, характером суспільних відносин, реформуванням політичної та економічної систем на принципово нових засадах. Пристосована в минулі роки до жорсткого зарегламентованого оточення, освіта сьогодні ввійшла в суперечність 3 новими, більш гнучкими і такими, що зазнають постійних трансформацій, вимогами українського суспільства - 3 ринковою економікою [1].

Реформування системи освіти завжди починається з певних змін у державному управлінні освітою та управлінні навчальними закладами. Тому ефективність освітніх процесів значною мірою залежить від ефективності управління діяльності. Оскільки період другої половини $\mathrm{XX}$ ст. багато у чому визначив напрямки і тенденції подальшого розвитку теорії управління в нашій країні, то саме в цей період визрівають передумови для радикальної зміни ії в останнє десятиліття XX ст.

Загальноприйнято, що заклад вищої освіти (3ВО) $є$ головною ланкою системи відтворення громадського інтелекту, підготовки і перепідготовки кадрів, отримання й поширення нових 
знань. Залежно від конкретної сфери вивчення громадських стосунків його можна й необхідно розглядати в різних іпостасях - як суб'єкт суспільства, держави й економіки країни, конкретної галузі та регіону; як центр зосередження осіб і колективів, а також як складну інтелектуальну систему управління.

Державний характер управління системою ЗВО базується на принципах: доступності для кожного громадянина усіх форм і типів освітніх послуг, що надаються державою; доступності й безоплатності здобуття повної загальної середньої освіти; обов'язковості повної загальної середньої освіти; рівності умов кожної людини для повної реалізації їі здібностей, таланту, всебічного розвитку; гуманізму, демократизму, пріоритетності загальнолюдських духовних цінностей; органічного зв'язку із світовою та національною історією, культурою, традиціями; незалежністю освіти від політичних партій, громадських і релігійних організацій; наукового характеру; інтеграції з наукою і виробництвом; взаємозв'язку 3 освітою інших країн; гнучкості й прогностичності системи освіти; єдності та наступності; безперервності й різноманітності; поєднання державного управління і громадського самоврядування [2].

Під економічною безпекою ЗВО розуміється економічна захищеність закладу освіти та інтересів його учасників від зовнішніх і внутрішніх загроз, що дозволяє надійно зберегти й ефективно використовувати для виконання своєї місії свій економічний потенціал. При цьому під місією 3ВО як суб’єкта економіки розуміється задоволення потреб населення (фізичних осіб), а також підприємств і організацій (юридичних осіб) в освітніх послугах і дослідженнях за допомогою створення й реалізації інтелектуальної продукції.

Сприйняття системи вищої освіти в Україні з економічних позицій сформувалося здебільшого у контексті неминучої модернізації системи вищої освіти у світлі тенденцій глобалізації, інформатизації та інновацій різноманітного характеру, активного використання зарубіжного досвіду, імплементації культурних та організаційних основ ринку як форми соціальних відносин. Такі обставини зумовили зміну ролі 3ВО в сучасному суспільстві та економіці України, вимог до їх діяльності та оцінних характеристик, спроби розповсюдити принципи ринкової економіки на діяльність закладів вищої освіти, тобто примусили вітчизняні 3ВО здійснювати свою діяльність межах приватно-утримувальної традиції, яка, будучи історично притаманною для англосак- сонських країн, характеризується самостійним зароблянням 3ВО коштів та порівняно незначною роллю держави в регулюванні їхньої діяльності. Тому, за Г. Д. Тюлєнєвим, 3ВО у приватно-утримувальній традиції орієнтовані винятково на професійне навчання та наукову діяльність, тобто на діяльність за моделлю економічної корпорації [3].

Чисельне оцінювання ризиків виникнення нових джерел загроз або ж активізації існуючих, на нашу думку, має здійснюватись у межах імовірнісної концепції організації управління у сфері освіти. Відповідно до цієї концепції, у зв 'язку з надзвичайною складністю і структури освітньої галузі, і характеру взаємовідносин між ऑii елементами, досягнення заздалегідь визначеної мети управління в освіті $€$ імовірнісною подією, а реалізація зазначеного управління - імовірнісним процесом. Тобто їхній формальний опис може бути здійснено за допомогою класичних інструментів теорії ймовірностей та математичної статистики. Із точки зору прогнозування виникнення або виявлення існування зовнішніх джерел загроз, безпека освіти в межах системно-кібернетичного підходу нами формулюється як здатність за рахунок реалізації навчально-виховних, інформаційних та управлінських процесів, параметри яких визначаються їх змістом, світоглядом, ресурсами, умовами і обмеженнями, а також оптимального здійснення економічної, фінансової, інформаційної, господарської, управлінської та інших видів діяльності в даній сфері, забезпечувати ефективну передачу теоретичних знань, практичних умінь і навичок від сучасного покоління до майбутнього. Крім того, має бути забезпечено найбільш повне задоволення сукупності потреб окремих індивідуумів у освітніх послугах та економіки і суспільства у висококваліфікованих фахівцях [4].

Внутрішні джерела загроз безпеки освіти також можуть активно створювати перешкоди щодо здійснення наведеної вище ії основної функції. При цьому, в даному випадку, дія загроз направлена в основному на реалізацію внутрішніх процесів системи 3 досягнення заздалегідь визначених чисельних параметрів результатів іiі функціонування (технічна, структурна, методична, інформаційна, поведінкова безпека). А дія зовнішніх загроз направлена в основному на зниження ефективності реалізації процесів обміну із навколишнім середовищем ресурсами, фінансами, енергією, інформацією та ентропією або ж їх повне припинення. Система освіти за своєю сутністю є відкритою, як і переважна більшість іï окремих елементів (підсистем), що мають складну ієрархічну 
внутрішню структуру. Існування цієї системи в умовах повної ізоляції $€$ фактично неможливим. Також неможливо забезпечити ії стовідсоткову відкритість. Це негайно приведе до розпаду, а також інтеграції окремих елементів (підсистем) до інших систем.

3 економічної позиції проблематика безпеки системи вищої освіти має вивчатися 3 позиції визнання держави інституцією, яка встановлює «правила гри» для ЗВО при виробленні ними нового знання та його комерціалізації. За умов дотримання таких правил інтелектуальний, інноваційний та інші види продуктів, що виробляє 3ВО, допускаються на відповідні ринки (освітніх послуг, інноваційних продуктів тощо). У такому випадку моніторинг загроз має здійснюватися стосовно кожного 3ВО, а кожне $3 \mathrm{BO}$ в межах наданих йому державою компетенцій, наявних ресурсів і можливостей самостійно намагається убезпечити свою діяльність. Держава втручається у боротьбу із загрозами лише тоді, коли вони набувають системного характеру (тобто стосуються переважної кількості 3ВО) і таким чином загрожують національній системі вищої освіти загалом або навіть національній безпеці країни. Проблематика безпеки системи вищої освіти актуалізувалася також і через дуальне сприйняття основного елемента 3ВО: за формою - у межах державо-утримувальної традиції, а по суті - за приватно-утримувальною. Тому актуальним і $є$ розгляд безпеки системи вищої освіти - як для самої системи, так і для національної безпеки [5].

Найсуттєвішою загрозою діяльності вітчизняних 3ВО, яка вже практично перетворилася на небезпеку (загроза при їі реалізації викликає негативні зміни в системі, але завдяки корегуванню елементів систему ще можна повернути до вихідного стану, тоді як небезпека при іiі peалізації викликає негативні зміни руйнівного характеру, після настання яких навіть корегування елементів системи не дозволяє повернути їі до вихідного стану), сьогодні слід визнати конкуренцію на ринку освітніх послуг, яка у наявному вигляді:

- несе дуже мало творчого, позитивного та конструктивного;

- не створює ефективного суперництва, тому що ведеться на асиметричному ринку освітніх послуг, часто неприйнятними для системи вищої освіти способами та прийомами (все ж таки освітня послуга є особливим продуктом);

- примушує 3ВО у конкурентній боротьбі керуватися запитами та уподобаннями основних споживачів наукового продукту - студентів, що призводить до зниження якості навчання.

Сьогодні активно поширюється думка, що у сучасній системі вищої освіти мають здійснюватися не лише підготовка майбутніх фахівців з певними компетенціями, а й створення та комерціалізація інновацій, інтелектуального продукту (в тому числі і для освітнього процесу), трансфер технологій та інше. За цією думкою, вітчизняні $3 \mathrm{BO}$ розглядаються як економічні корпорації, діяльність яких становить виробництво та комерціалізація знань у таких формах як надання освітніх послуг відповідно до запитів споживачів (але за вимогами, що встановлені державою у стандартах освітньої діяльності та стандартах вищої освіти), продаж патентів, ліцензій, виконання робіт на замовлення тощо. ЗВО як економічна корпорація буде успішною, якщо зможе не лише «виробити» нові знання, а й вигідно їх продати [6].

Механізм реалізації функцій держави відбувається через систему, що формується з методів, важелів й інструментів впливу з відповідним забезпеченням. Удосконалення державної політики в сфері вищої освіти необхідно впроваджувати саме через основні складові механізму державного управління.

Механізми забезпечення економічної безпеки в системі вищої освіти зумовлено економічною безпекою вищих навчальних закладів, що складають систему: якщо переважна більшість вишів перебуватиме в економічній безпеці, тоді за індуктивною логікою можна стверджувати про економічну безпеку в системі вищої освіти країни. Стосовно забезпечення безпеки 3ВО необхідно відзначити, що оцінювання рівня економічної безпеки ЗВО за функціональними складовими на основі статистичних методів досить складне через їхню низьку математичну формалізацію. Проте таке оцінювання проводити необхідно, тому індикатори економічної безпеки $3 \mathrm{BO}$ поділяють за кожною з ії складових і розраховують їх на основі оцінювання збитків, завданих інтересам 3ВО, та ефективності заходів щодо запобігання їм. Найбільш розповсюдженим підходом до оцінювання економічної безпеки з використанням сукупності показників $€$ індикаторний метод. Оцінювання економічної безпеки з використанням індикаторного підходу базується на системі індикаторів, до точності визначення яких висуваються високі вимоги [7].

Тож розглянемо це більш детальніше. За формами впливу методи державного управління вищих навчальних закладів, на нашу думку, можна класифікувати як прямі, непрямі та неформальні (табл. 1). 


\section{КЛАСИФІКАЦІЯ МЕТОДІВ ДЕРЖАВНОГО УПРАВЛІННЯ ЗАКЛАДАМИ ВИЩОЇ ОСВІТИ ЗА ФОРМАМИ ВПЛИВУ}

$\begin{array}{cc}\begin{array}{c}\text { Методи } \\ \text { державного } \\ \text { управління }\end{array} & \begin{array}{c}\text { Напрями } \\ \text { реалізації }\end{array} \\ \text { Прямі } & \text { Адміністративні } \\ \text { Імперативні } \\ \text { Специфічні } \\ \text { Пепрямі } & \text { Правові } \\ & \text { Економічні } \\ & \text { Індикативні } \\ \text { Неформальні } & \text { Соціальні } \\ & \text { Технологічні }\end{array}$

\author{
Інструменти
}

Державні контракти та державні замовлення; субсидії, субвенції та дотації; ліцензування; встановлення фіксованих цін, стандартів, нормативів та обсягів прямих бюджетних витрат

Зниження податкових ставок, регулювання облікових ставок та норм амортизації необоротних активів, встановлення індикативних цін

Підвищення рівня інноваційної культури суспільства, створення центрів дистанційного навчання із застосуванням сучасних телекомунікаційних технологій

\section{Джерело: складено автором}

Методи прямого впливу безпосередньо діють на функціонування суб'єктів управління. Можуть бути адміністративними (що базуються на використанні сили державної влади через заборону, дозвіл, примушування) або імперативними (як різновид адміністративного методу, тобто владний, наказовий).

Для управління закладами вищої освіти, які повністю або частково знаходяться в державній власності, можуть також застосовуватися специфічні методи управління. Інструментами прямого втручання в діяльність вищих закладів освіти можуть бути державні контракти та державні замовлення, субсидії субвенції, дотації, ліцензування, а також встановлення фіксованих цін, стандартів, нормативів та обсягів прямих бюджетних витрат [8].

Методи непрямого впливу - це сукупність опосередкованих засобів державного управління на діяльність навчальних закладів через підсистему правових, економічних та індикативних методів. Підсистема правових методів визначає правовий простір вищої освіти та регламентує діяльність її суб'єктів через закони й законодавчі акти.

Економічні методи державного управління пов'язані зі створенням державою фінансових чи матеріальних стимулів, здатних впливати на економічні інтереси $3 \mathrm{BO}$ й обумовлювати їхню поведінку. Індикативні методи, як різновид непрямого впливу державного управління, мають намір опосередкований, орієнтовний та рекомендований характер. Інструментами непрямих методів можуть бути зниження податкових ставок, регулювання облікових ставок та норм амортизації необоротних активів, встановлення індикативних цін на деякі види активів.

Останнім часом набувають актуальності неформальні методи державного управління, які ми поділяємо на соціальні та технологічні. Реалізація цих методів може відбуватися шляхом підвищення рівня інноваційної культури суспільства через підтримку наукових і науковопопулярних видань, наукових видавництв, розвиток освітніх і науковопопулярних програм у засобах масової інформації, а також шляхом створення центрів дистанційного навчання із застосуванням сучасних телекомунікаційних технологій, забезпечення наукового та навчального процесу сучасними комп'ютерними технологіями, популяризацію інформатизації тощо.

Крім того, прихованим елементом економічної безпеки $3 В О$ є стабільність та стійкість - можливість продовжувати діяльність навіть у разі погіршення умов зовнішнього середовища та актуалізації загроз. Частково стабільність та стійкість $є$ похідними від економічної незалежності, але повністю нею не визначаються. Стабільність та стійкість як елемент економічної безпеки ЗВО характеризують певний «запас міцності», що виникає внаслідок минулої діяльності.

Тому стабільність та стійкість ЗВО крім суто фінансового стану визначаються його репутацією, наявністю інших джерел фінансування, співвідношенням доходів та витрат, наявністю резервів, якісних трудових ресурсів тощо. Нарешті, у перспективі важливим елементом економічної безпеки ЗВО стає здатність до розвитку та прогресу, тобто можливість не лише 
здійснювати поточну діяльність, а забезпечувати саме розширене відтворення використовуваних у навчальному процесі ресурсів - матеріальних, інформаційних, кадрових, клієнтських тощо з метою формування цільових позитивних змін.

Здатність до розвитку та прогресу не впливає на економічну безпеку 3ВО у поточному періоді, але $\epsilon$ iї основою у майбутньому. Виключно пасивна реакція на загрози у зовнішньому середовищі, які виникають, неспроможна забезпечити належну економічну безпеку, оскільки ЗВО (як і будь-який суб'єкт господарювання) буде постійно запізнюватися стосовно виникнення загроз та ризиків у зовнішньому середовищі. Саме тому здатність до розвитку та прогресу, цільове створення позитивних змін, які принесуть результат у майбутньому, $є$ хоча й найменш відчутним, але від цього не менш важливим елементом економічної безпеки $3 \mathrm{BO}$.

Безумовно, зазначені елементи економічної безпеки ЗВО є взаємопов'язаними. Кожен 3 них визначає інші або, як мінімум, впливає на них: стабільність та стійкість неможливі без економічної незалежності; саме наявність економічних ресурсів забезпечує можливість прогресу та розвитку, який є запорукою стабільності у майбутньому та основою формування майбутніх грошових потоків. Але, водночас, змістово всі три елементи економічної безпеки ЗВО $є$ несинонімічними й незалежними один від одного. Цінність їхнього виділення та чіткої ідентифікації зрозуміла: для забезпечення економічної безпеки ЗВО мають бути сформовані всі три елементи, оскільки відсутність хоча 6 одного з них робить економічну безпеку вкрай хиткою (у довгостроковому періоді) або взагалі не дозволяє стверджувати про наявність будьякої економічної безпеки.

Зазначимо, що особливістю формування державної політики у сфері освітніх послуг в умовах євроінтеграції та інноваційного розвитку України $\epsilon$ те, що в ході розвитку ринкових відносин і стабілізації економіки функції прямого впливу держави на сферу освіти будуть звужуватися [9].

Отже, удосконалення державної політики в сфері вищої освіти треба більше зосередити на непрямому та неформальному методах механізмів державного управління вищими навчальними закладами. До другої важливої складової системи реалізації державної політики відносяться важелі механізмів державного управління освітньою діяльністю. На нашу думку останні тісно пов’язані з характером надання освітніх послуг і для всіх різновидів механізмів державного управління (як то правового, фінансового та ін.) не будуть відрізнятися.
Базовими серед них ми вважаємо:

- економічну доцільність (тобто мотивація освітньої діяльності);

- обгрунтування обсягів і джерел фінансування;

- дотримання правових регуляторів.

Отже, на наш погляд, удосконалення механізмів державного управління в освітній галузі необхідно розглядати системно в нерозривному взаємозв'язку: “методи - важелі - інструменти”, а особливості формування державної політики має відбуватися саме у відповідному забезпеченні механізмів іiі реалізації, що приймаються в межах компетенції органів державного управління.

Доцільно зазначити, що особливістю розвитку цієї галузі науки в зарубіжних країнах стала іiі опора на різноманітні соціальні, педагогічні, психологічні теорії. Це привело до концептуалізації розвитку теорії управління освітніми установами, що безсумнівно, можна вважати головною іiі особливістю. Управління закладами вищої освіти - це складна структура, що включає духовні та матеріальні процеси. Основним компонентом $3 В О$ як соціальної системи $є$ людина. Але, крім людей, для нормального його функціонування необхідні різноманітні речі, технічні об'єкти, яких згодом стає все більше. Ці матеріальні об'єкти можуть бути розглянуті як самостійні елементи навчального закладу як системного утворення. Тому управління навчальним закладом - це управління насамперед людьми і відносинами між ними, але й управління речами.

Комплексний механізм державного управління сфери вищої освіти, що потребує удосконалення, може складатися із таких видів механізмів як:

- правовий (регулює відносини між державою та суспільством через закони і постанови Верховної Ради України, укази Президента, постанови Кабінету Міністрів України, а також накази відповідних міністерств і відомств);

- організаційний (визначає об’єкти, суб’єкти державного управління, їх цілі, завдання, функції, методи управління та організаційні структури через методичні вказівки, інструкції, норми, нормативи й стандарти);

- фінансовий (забезпечує регулювання фінансової, інвестиційної та інноваційної діяльності шляхом складання стратегічних планів розвитку, поточного бюджетування та фінансування закладів вищої освіти);

- інформаційний (запроваджує інформаційне забезпечення в державному управлінні через складання звітності 3ВО, статистичних збірників та застосування Інтернет-ресурсів). 
Система вищої освіти, як і будь-яка соціальноекономічна система спроможна виконувати своє призначення та результативно функціонувати за наявності низки умов, однією з важливих серед яких сьогодні є перебування системи у стані безпеки (звичайно ж, відносної, адже абсолютної безпеки не існує). 3 позицій захисного підходу загрози системі вищої освіти, якщо їм не протидіяти, перетворюються на небезпеки, які, якщо реалізуються, завдають системі такої шкоди, яку в низці випадків не можна компенсувати або для цього потрібно багато часу, зусиль і ресурсів.

Основний елемент системи вищої освіти України сьогодні має змішаний статус - начебто суспільна інституція і начебто економічна корпорація. Невизначеність статусу вітчизняних ЗВО разом із відсутністю програмно задекларованих державою орієнтирів та векторів розвитку системи вищої освіти, певка усунутість держави від загроз системі вищої освіти та ії̈ вичікувальна позиція значно послаблюють можливості ЗВО реагувати на численні загрози їхній діяльності (у статті зазначено лише типові загрози). По суті, вітчизняні ЗВО змушені приймати загрози, що реалізуються (реактивна політика у безпекозабезпечувальній діяльності), а вже потім якимось чином усувати наслідки їх реалізації. Коли ЗВО зайняті моніторингом загроз, спостереженням за їхньою реалізацією та усуненням ії наслідків, то про якість освіти не йдеться.

\section{ВИСНОВКИ ТА ПЕРСПЕКТИВИ ПОДАЛЬШИХ ДОСЛІДЖЕНЬ}

Таким чином, на основі проведеного аналізу визначено, що особливістю формування механізмів державного управління вищими навчальними закладами в умовах євроінтеграції та інноваційного розвитку держави є звуження функції прямого впливу держави на сферу освіти, що надасть можливість більше зосередитися на методах непрямого й неформального впливу на освітню сферу.

Економічна безпека вітчизняних $3 \mathrm{BO}$ сьогодні має визначатися та забезпечуватися виходячи 3 історичної роли ЗВО як суспільного інституту, що має високу соціальну важливість, та вимушеної роли ЗВО як економічного агента, до виконання якої вітчизняні вищі навчальні заклади примушують через обмежене державне фінансування та невиправдане прагнення у найкоротший термін перебудувати їхню діяльність на зразок зарубіжних вишів країн з приватно-утримувальною тенденцією у системі вищої освіти. Для системи вищої освіти України більш характерна державо-утримувальна традиція, за якою традиційно значними є роль держави у фінансуванні та регулювання діяльності 3ВО та цільове соціальне навантаження діяльності. Але внаслідок імплементації культурних та організаційних основ ринку як форми соціальних відносин дедалі все більше українські 3ВО вимушені працювати за приватно-утримувальною традицією, яка історично характерна для англосаксонських країн, характеризується самостійним зароблянням $3 \mathrm{BO}$ коштів та порівняно незначною роллю держави у регулюванні навчального процесу. Але в Україні держава не має наміру відмовитися від тотального регулювання діяльності ЗВО. Забезпечення економічної безпеки ЗВО визначально залежить від сприйняття ЗВо. Від відповіді на це запитання вирішальною мірою залежать орієнтири розвитку екосеседа. Безумовно, повертатися до моделі ЗВО радянських часів і недоречно, і неможливо, а комерціалізація у ринкових умовах неминуче явно чи ні присутня у будь-якому виді діяльності. Тому слід подумати про економічну модель діяльності вітчизняних $3 \mathrm{BO}$, яка зовсім не є тотожною моделі економічної корпорації. Перехід вітчизняних $3 В О$ виключно на модель економічної корпорації, на нашу думку, призведе до суттєвих суспільних втрат (ix не завжди можна виміряти за допомогою вартісних показників) - до руйнування національних цінностей, втрати незамінних форм національної культури, дефекту світогляду кількох поколінь.

Тож, в подальших дослідженнях доцільно зупинитись на удосконаленні правового статусу закладів вищої освіти; запровадженні сучасного організаційно-фінансового та інформаційного забезпечення в державному управлінні закладами, i, зокрема, розробка та впровадження наукового підходу до нього. Необхідно продовжувати дослідження формування державної політики у сфері вищої освіти з метою ії̈ удосконалення за допомогою впровадження сучасних методологій.

\section{СПИСОК ВИКОРИСТАНИХ ДЖЕРЕЛ}

1. Андрущенко В.П. Теоретико-методологічні засади модернізації вищої освіти в Україні на рубежі століть. Вища освіта України : збірник. Київ, 2001. № 2. С. 5-13.

2. Домбровська С.М. Трансформація державного управління освітньої політики України в контексті подальшого реформування та стабілізації. Актуальні проблеми державного управління : зб. наук. пр. Харків, 2010. Вип. 1. С. 293-298. 
3. Яблочніков С.Л. Педагогічна кібернетика: системно-кібернетичний підхід до управління в освіті : монографія. Вінниця, 2009. 406 с.

4. Орлов П.І., Духов П.І. Основи економічної безпеки фірми : навч. посібник. Харків : ТОВ Прометей-Прес, 2004. 284 с.

5. Луговий В.І. Управління освітою: навч. посіб. для слухачів, аспірантів, докторантів спеціальності «Державне управління». Київ : Вид-во УАДУ, 1997. 302 с.

6. Дмитриев С.М., Ширяев М.В., Митяков С.Н. Экономическая безопасность технического вуза: система индикаторов. Высшее образование в России : журнал. 2014. № 3. С. 11-20.

7. Плахотнікова Л.О. Удосконалення умов фінансування вищої освіти як основного чинника підготовки фахівців. Формування ринкових відносин в Украйні (укр.): журнал. 2008. № 1. C. $141-146$.

8. Куркін М.В. Контроль та захист економічної безпеки діяльності підприємства : навч. посібник. Харків : ІНЖЕК, 2010. 300 с.

9. Яременко Л.М. Напрями вдосконалення механізму фінансування вищої освіти в Україні. Формування ринкових відносин в Україні (укр.) : журнал. 2007. № 7. С. 153-157.

\title{
ЭКОНОМИЧЕСКАЯ БЕЗОПАСНОСТЬ УЧЕБНОГО ЗАВЕДЕНИЯ КАК СОСТАВЛЯЮЩАЯ ПРОЦЕССА ГОСУДАРСТВЕННОГО УПРАВЛЕНИЯ ОБРАЗОВАНИЕМ
}

\author{
Гаман Петр Ильич, \\ доктор наук по государственному управлению, доцент, \\ начальник отдела публичного управления гражданской защитой, \\ научно-исследовательского чентра мероприятий гражданской защиты, \\ Украинский научно-исследовательский институт гражданской защиты, \\ 2. Киев, Украина. \\ ORCID iD 0000-0002-3239-8936 \\ e-mail:haman_p.i@ukr.net
}

\section{Гаман Наталья Александровна,}

кандидат наук по государственному управлению, старший преподаватель каредры маркетинга, менеджмента и управления бизнесом, Уманский государственный педагогический университет имени Павла Тычины, 2. Умань, Украина ORCID iD 0000-0003-4999-6163 e-mail:haman_n.o@ukr.net

Аннотация. Цивилизационные процессы начале XXI века отмечены глобализачией коммуникации, формированием идеологии информачионного общества, решающим образом влияют на международную среду, радикально меняют международную политику, национальные, внешне- и внутриполитические доктрины, обусловливают необходимость выяснения приоритетов и разработки оптимальных программ в политической, экономической, социальной и культурной сферах. Система образования любого государства является неотъемлемой частью общей совокупности ее социально-экономических отношений. Реализация адекватного анализа функционирования и развития образовательных процессов и систем, организачия эффрективного управления ими, обеспечения соответствующего уровня качества результатов деятельности фактически невозможны без учета их взаимодействия с окружающей средой, а также минимизации рисков возникновения конфликтов интересов. Общая безопасность страны может быть обеспечена только за счет одновременного решения этого вопроса в ряде различных областей, а именно: военной, технической, технологической, экономической, финансовой, политической, экологической, информачионной и тому подобное. Информационная доминанта усиливает эффектт глобальной политики, определяет значимость стран в мировой иерархии, выступает фактором международных действий, инструментом дипломатии и глобальной стратегии мирового порядка. Для высшего образования Украины такие прочессы рассматриваются через призму задач вхождения в Европейское пространство высшего образования (Европейского пространства высшего образования), исходным кониептом которого с 2005 года является реализаиия принципов Болонского прочесса. Образовательная сфера не может быть исключением из приведенного выше перечня, хотя бы в связи с тем, что первоочередной задачи ее функ- 
ционирования является подготовка высококвалифицированных специалистов для всех без исключения перечисленных отраслей. И в этом смысле аспекты безопасности образования являются определяющими для всех остальных сфер социально-экономической жизни.

Ключевые слова: учреждения высшего образования; государственное управление; инструменты государственного управления; безопасность; образовательные услуги; органы государственной власти.

\title{
ECONOMIC SECURITY OF EDUCATIONAL INSTITUTION AS A COMPOSITION OF THE PROCESS OF STATE EDUCATION MANAGEMENT
}

\author{
Petro Haman, \\ doctor of sciences in public administration, associate professor, \\ head of the public management department for civil protection \\ of the research center for civil protection, \\ Ukrainian research institute for civil protection, Kyiv, Ukraine \\ ORCID iD 0000-0002-3239-8936 \\ e-mail:haman_p.i@ukr.net
}

\author{
Natalia Gaman, \\ candidate of sciences in public administration, \\ senior lecturer of the department of marketing, \\ management and business management, \\ Pavlo Tychyna Uman state pedagogical university, \\ Uman, Ukraine \\ ORCID iD 0000-0003-4999-6163 \\ e-mail:haman_n.o@ukr.net
}

\begin{abstract}
Annotation. The civilization processes of the beginning of the $27^{\text {st }}$ century are characterized by the globalization of communication, the formation of the ideology of the information society, which have a decisive influence on the international environment, radically change international politics, national, foreign and domestic political doctrines, necessitating the identification of priorities and the development of optimal programs in the political, economic, social and cultural spheres. The system of education of any state is an integral part of the general set of its socio-economic relations. The implementation of an adequate analysis of the functioning and development of educational processes and systems, the organization of their effective management, ensuring the appropriate level of quality of performance is virtually impossible without taking into account their interaction with the environment, as well as minimizing the risks of conflicts of interest. The general security of the country can be ensured only at the expense of the simultaneous solution of this issue in a number of different fields, namely: military, technical, technological, economic, financial, political, environmental, information, etc. The information dominant strengthens the effect of global politics, determines the importance of countries in the world hierarchy, acts as a factor in international influences, an instrument of diplomacy and a global strategy of world order. For higher education in Ukraine, such processes are considered through the prism of the objectives of joining the European Higher Education Area (EHEA), the initial concept of which since 2005 is the implementation of the principles of the Bologna process. The educational sphere can not be an exception to the above list, at least in connection with the fact that the primary task of its functioning is the training of highly skilled professionals for all the industries listed without exception. And in this sense, the security aspects of education are crucial for all other spheres of socio-economic life.
\end{abstract}

Key words: institutions of higher education; governance; government instruments; security; educational services; public authorities.

\section{REFERENCE (TRANSLATED AND TRANSLITERATED)}

1. Andrushchenko V.P. (2001). Teoretyko-metodolohichni zasady modernizatsii vyshchoi osvity v Ukraini na rubezhi stolit. Kyiv. Vyshcha osvita Ukrainy.Vol. 2. 5-13. [in Ukrainian]

2. Dombrovska S.M. (2010). Transformatsiia derzhavnoho upravlinnia osvitnoi polityky Ukrainy v konteksti podalshoho reformuvannia ta stabilizatsii. Kharkiv. Aktualni problemy derzhavnoho upravlinnia. Vol. 1. 293-298. [in Ukrainian] 
3. Yablochnikov S.L. (2009). Pedahohichna kibernetyka: systemno-kibernetychnyi pidkhid do upravlinnia v osviti. Vinnytsia. $406 \mathrm{p}$.

4. Orlov P.I., Dukhov P.I. (2004). Osnovy ekonomichnoi bezpeky firmy. Kharkiv. TOV Prometei-Pres. 284 p. [in Ukrainian]

5. Luhovyi V.I. (1997). Upravlinnia osvitoiu: navch. posib. dlia slukhachiv, aspirantiv, doktorantiv spetsialnosti «Derzhavne upravlinnia». Kyiv. UADU. 302 p. [in Ukrainian]

6. Dmytryev S.M., Shyriaev M.V., \& Mytiakov S.N. (2014). Ekonomycheskaia bezopasnost tekhnycheskoho vuza: systema yndykatorov. Visshee obrazovanye v Rossyy. Vol. 3. 11-20. [in Russian] 7. Plakhotnikova L.O. (2008). Udoskonalennia umov finansuvannia vyshchoi osvity yak osnovnoho chynnyka pidhotovky fakhivtsiv. Formuvannia rynkovykh vidnosyn v Ukraini. Vol. 1. 141-146. [in Ukrainian]

8. Kurkin M.V. (2010). Kontrol ta zakhyst ekonomichnoi bezpeky diialnosti pidpryiemstva. Kharkiv. INZhEK. 300 p. [in Ukrainian]

9. Yaremenko L.M. (2007). Napriamy vdoskonalennia mekhanizmu finansuvannia vyshchoi osvity v Ukraini. Formuvannia rynkovykh vidnosyn v Ukraini. Vol 7. 153-157. [in Ukrainian] 